\title{
Effect of high dose inhaled acetic acid on airway responsiveness in Fischer rats
}

\author{
AP Ariel MD, HG Furlott, KR Chapman MD, AS Slutsky MD, P Webster MD, N Zamel MD, \\ SM Tarlo MB BS \\ Department of Medicine, University of Toronto, Toronto, Ontario
}

\begin{abstract}
AP Ariel, HG Furlott, KR Chapman, AS Slutsky, P Webster, N Zamel, SM Tarlo. Effect of high dose inhaled acetic acid on airway responsiveness in Fischer rats. Can Respir J 1998;5(5):349-354.
\end{abstract}

BACKGROUND: Sudden, severe airway injury has been associated with an acute, and at times persisting, airway hyper-responsiveness with clinical features of asthma, termed reactive airways dysfunction syndrome (RADS). An attempt was made to develop a rat model of RADS by exposing inbred Fischer rats to inhaled $8 \mathrm{~N}$ acetic acid for 2 mins (13 $\mathrm{N}$ inhalation was lethal).

METHODS: Lung resistance $\left(\mathrm{R}_{\mathrm{L}}\right)$ and lung elastance $\left(\mathrm{E}_{\mathrm{L}}\right)$ were measured in 14 eight- to 10 -week old male rats. Baseline responsiveness to methacholine was quantified by calculating the dose required for doubling of $\mathrm{R}_{\mathrm{L}}$. The next day, the study group $(\mathrm{n}=11)$ was exposed to aerosolized acetic acid. Control animals $(\mathrm{n}=3)$ were similarly exposed to buffered saline solution.

RESULTS: Acetic acid exposure resulted in a significant $(\mathrm{P}<0.02)$ increase in $\mathrm{R}_{\mathrm{L}}$ (by $80 \%$ ) and $\mathrm{E}_{\mathrm{L}}$ (by 67\%), lasting less than 10 mins postexposure, but no significant change in methacholine responsiveness at one day and seven days postexposure.

CONCLUSIONS: Failure to induce persistent airway hyper-responsiveness may relate to the choice of animal, choice of irritant, or insufficient level or duration of exposure, or may reflect a lack of individual predisposing cofactors such as smoking or underlying asthmatic predisposition.

Key Words: Irritant-induced asthma, Occupational asthma, Reactive airways dysfunction syndrome

\section{Effet de l'inhalation d'une forte dose d'acide acétique sur la réponse des voies aériennes de rats Fisher}

HISTORIQUE : Une atteinte soudaine et grave des voies aériennes a été associée à une hyperréactivité bronchique aiguë, quelquefois persistante, accompagnée de manifestations cliniques d'asthme, et appelée « Reactive Airways Dysfunction Syndrome » ou « RADS » [syndrome d'irritation aiguë des bronches]. Un modèle « rat » de RADS a été créé en exposant des rats Fisher de race pure à une inhalation d'acide acétique $8 \mathrm{~N}$ pendant 2 minutes (une inhalation $13 \mathrm{~N}$ était létale).

MÉTHODES : La résistance pulmonaire ( $\mathrm{R}$ ) et l'élastance pulmonaire $(\mathrm{E})$ ont été mesurées chez 14 rats mâles âgés de huit à dix semaines. La réponse de base à la méthacholine a été quantifiée en calculant la dose requise pour multiplier la R par deux. Le jour suivant, le groupe à l'étude $(\mathrm{n}=11)$ a été exposé à de l'acide acétique par inhalation. Les animaux du groupe témoin $(n=3)$ ont été exposés de la même façon à une solution saline tampon.

RÉSULTATS : L'exposition à l'acide acétique a causé une augmentation significative $(\mathrm{P}<0,02)$ de la $\mathrm{R}_{i}(\mathrm{de} 80 \%)$ et de l' $\mathrm{E}_{\mathrm{i}}$ (de $67 \%$ ) qui a persisté pendant moins de 10 minutes après l'exposition ; cependant, on a noté aucun changement significatif dans la réponse à la méthacholine le premier jour et sept jours après l'exposition.

CONCLUSIONS : Le fait de n'avoir pas réussi à provoquer une hyperréactivité durable des voies aériennes peut provenir du choix de l'animal, du choix de la substance irritante, d'un niveau ou d'un temps d'exposition insuffisants, ou bien reflète l'absence de cofacteurs individuels prédisposants tels que le tabagisme ou une prédisposition sous-jacente à l'asthme. 
$\mathrm{R}$ eactive airways dysfunction syndrome (RADS) is an asthma-like syndrome described by Brooks and colleagues (1) in 1985. The syndrome is characterized by asthma symptoms and nonspecific airway hyper-responsiveness (AHR) beginning within $24 \mathrm{~h}$ of a single exposure to a high concentration of a respiratory irritant and persisting for at least three months in an individual with no known underlying respiratory disease. Since the initial description of RADS, other reports have confirmed this syndrome (2-5), and further reports have suggested that a similar syndrome may occur with recurrent high level irritant exposures $(6,7)$ or even with moderate exposures $(8,9)$. The term 'irritantinduced asthma' has been used to describe the response associated with these syndromes, which include RADS.

Diagnosis of irritant-induced asthma is based on the exposure history, timing of onset of symptoms, demonstration of AHR and lack of previously documented respiratory disease. No specific investigations confirm the diagnosis; the diagnosis is tenuous and cannot be distinguished from the onset of nonirritant asthma in an individual patient, particularly if the exposure has been chronic or nonmassive without a single, unusually high exposure within $24 \mathrm{~h}$ of onset of symptoms. In addition, the majority of reported patients had smoked cigarettes, and underlying AHR could not be excluded. Therefore, controversy as to whether this syndrome exists except when strictly defined as RADS remains (10); the diagnosis can seldom be made with absolute certainty, even in patients suspected of having RADS, because pre-exposure assessment of lung function is generally absent.

Prospective clinical studies have not clearly documented de novo induction of long standing AHR by moderate irritant exposures. A report of workers exposed to calcium oxide

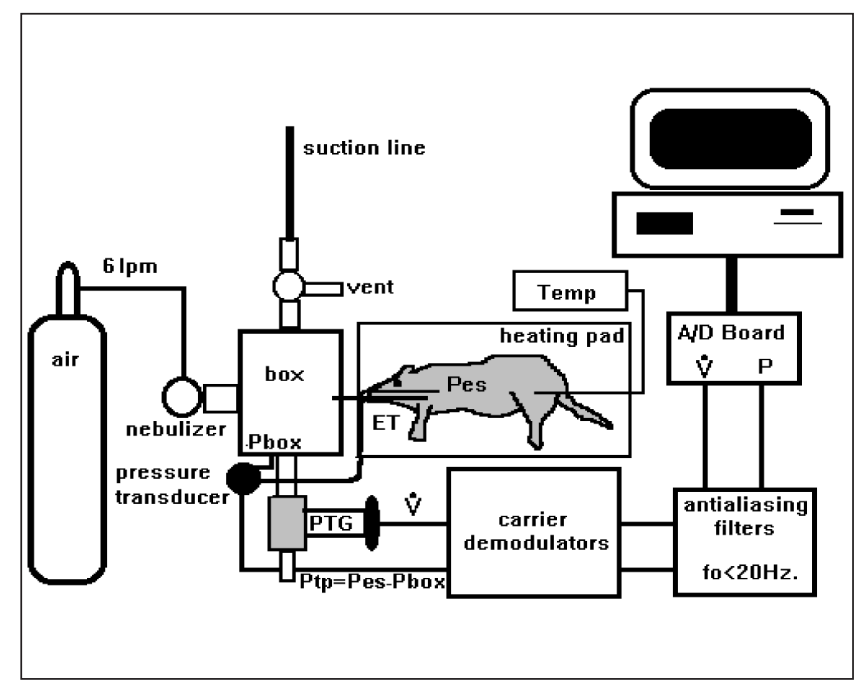

Figure 1) The experimental setup. The rat is lying in a lateral decubitus position on a heating pad. Orotracheal tube, esophageal catheter and rectal thermistor are placed. The transducers, data acquisition system and aerosol delivery setup are shown. A/D Analogue/digital; ET Endotracheal catheter; lpm Litres per minute; $P$ Pressure; Pbox Box pressure; Pes Esophageal pressure; PTG Pneumotachograph; Ptp Transpulmonary pressure; $\dot{V}$ Airflow dust did not find an increase in new-onset asthma (11). However, recurrent exposures to high levels of chlorine have been associated with an increased prevalence of asthma and AHR (12). A spill of glacial acetic acid was reported to induce RADS in four exposed individuals with an apparent doseresponse relationship (4). In that study, three of 14 subjects with high level exposure developed RADS compared with one of 30 with moderate exposure.

Because an animal model of RADS would allow better determination of the pathogenesis of this syndrome, the present study was designed to develop such a model. A previous report (4) of the development of RADS following a high dose of acetic acid prompted the investigation of the effect of high dose inhaled acetic acid in an animal model. Fischer rats were chosen due to their relative baseline AHR (13). The short term effects of a single high dose exposure of inhaled methacholine (Mch) on airway responsiveness, lung resistance $\left(R_{L}\right)$ and lung elastance $\left(E_{L}\right)$ were assessed. It was hypothesized that this exposure would increase $\mathrm{R}_{\mathrm{L}}$ and airway responsiveness.

\section{ANIMALS AND METHODS}

Animal subject approval: Institutional approval was obtained for the use of the animals in this study.

Animals, anesthesia and preparation: Fourteen male Fischer rats eight- to 10 -weeks of age and weighing 130 to $330 \mathrm{~g}$ (Charles River) were housed in a conventional rat colony at the Toronto General Hospital Animal Centre. Rats were first sedated with xylazine ( $7 \mathrm{mg} / \mathrm{kg}$ intraperitoneally) and anesthetized 15 to 20 mins later with pentobarbital sodium (30 mg/kg intraperitoneally). Orotracheal intubation was performed using a $6 \mathrm{~cm}$ polyethylene catheter (PE-240). A saline filled-catheter (PE-160) was placed in the lower third of each animal's esophagus. The animal was placed on a heating pad, in a right decubitus position. Rectal temperature, monitored using an electronic thermometer, was maintained constant throughout the experiment.

Measurement of lung mechanics: The end of the orotracheal tube was connected to a small $(250 \mathrm{~mL})$ plastic box (Figure 1). The frequency response of the box was flat up to $10 \mathrm{~Hz}$. A Fleisch number 0 pneumotachograph (PTG) (Fleisch, Lauzanne, Switzerland) coupled to a differential pressure transducer (MP-45; $\pm 2 \mathrm{~cm} \mathrm{H}_{2} \mathrm{O}$, Validyne Corporation, California) was attached to the other end of the box to measure airflow. The ports connecting the box to the nebulizer and suction source were clamped during periods of data acquisition. An index of transpulmonary pressure,

$$
P t p=P e s-P b o x
$$

where Pes is the esophageal pressure and Pbox is the pressure inside the box, was measured by connecting the esophageal catheter to one port of a differential pressure transducer (Omega Engineering, Inc, Model PX143; $\pm 68 \mathrm{~cm} \mathrm{H} 2 \mathrm{O}$ ). The other port of the transducer was connected to the box. The animal breathed spontaneously throughout the experiment. Analogue transpulmonary pressure and flow signals were 
conditioned by antialiasing filters and sampled at $200 \mathrm{~Hz}$ with an analogue to digital board (DT2801-A, Data Translation, Massachusettes) installed in a microcomputer. A commercial software (RHT-InfoDat Inc) was used. Volume was obtained by numerically integrating the flow signal. $\mathrm{R}_{\mathrm{L}}$ and EL were derived by fitting the equation of motion by multiple linear regression.

Aerosol generation: Aerosols were generated using a Hudson nebulizer (Model 1700, Hudson Oxygen Therapy, California) containing $3 \mathrm{~mL}$ of solution, which was driven by compressed air source at an airflow of $6 \mathrm{~L} / \mathrm{min}$ (nebulizer output $0.17 \mathrm{~mL} / \mathrm{min}$ ). The nebulizer was connected to the plastic box. During aerosol delivery the PTG port of the plastic box was clamped, and the suction outlet vented to the room. A plastic hood was placed on the vent to prevent contamination of the room. Immediately following each aerosol exposure, the nebulizer port was clamped and the box was flushed by sucking room air through the PTG port.

Mch challenge: Rats inhaled aerosols of normal saline and progressively doubling concentrations of Mch, each administered for $30 \mathrm{~s}$. Mch concentrations ranged from 0.128 to $32 \mathrm{mg} / \mathrm{mL}$. The peak value of $\mathrm{R}_{\mathrm{L}}$ was measured before and after inhalation of saline, and after each of the concentrations of Mch. Approximately 3 mins elapsed between the administration of each Mch concentration. The concentration of Mch required to double $\mathrm{R}_{\mathrm{L}}\left(\mathrm{EC}_{200} \mathrm{R}_{\mathrm{L}}\right)$ was obtained by log interpolation.

Acetic acid exposure: Animals were exposed to acetic acid by having them inhale a nebulized solution of acetic acid for 2 mins, using the same delivery method. The nebulizer was changed, and the plastic box was thoroughly flushed immediately following the acid exposure. An $8 \mathrm{~N}$ acetic acid solution was chosen based on preliminary experiments. Inhalation of $8 \mathrm{~N}$ acetic acid caused a transient increase in $\mathrm{R}_{\mathrm{L}}$ and $\mathrm{E}_{\mathrm{L}}$ (Figure 2). Lower concentrations ( 2 to $4 \mathrm{~N}$ ) did not cause a significant postexposure increase in $\mathrm{R}_{\mathrm{L}}$, whereas inhalation of a $13 \mathrm{~N}$ solution was lethal.

Study groups and follow-up protocol: Eleven animals (study group) were exposed to $8 \mathrm{~N}$ acetic acid, as previously described. Three rats were given saline inhalation (control group). $\mathrm{R}_{\mathrm{L}}$ was measured before the acetic acid exposure and at $1,5,15$ and 30 mins postexposure. Airway responsiveness (Mch challenge) was conducted at baseline (day B) and repeated $24 \mathrm{~h}$ (day 1) and one week (day 7) postexposure.

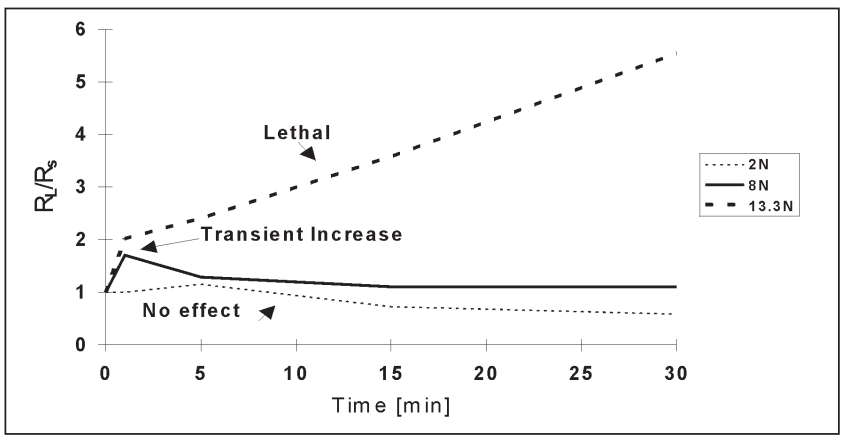

Figure 2) Postexposure lung resistance ratio normalized to baseline postsaline inhalation value $\left(R_{L} / R_{S}\right)$ following the inhalation of three different acetic acid concentrations. Each line represents a single animal. Addition of $8 \mathrm{~N}$ acetic acid caused a transient $(70 \%)$ increase in $R_{L} / R_{S}$

Statistical analysis: Group results are expressed as means \pm $\mathrm{SE}$, except for $\mathrm{EC}_{200} \mathrm{R}_{\mathrm{L}}$ values, which are reported as geometric means. The significance of the difference between means was evaluated using ANOVA with Tukey's honestly significantly different post hoc comparison. $\mathrm{EC}_{200} \mathrm{R}_{\mathrm{L}}$ data were $\log$ transformed before ANOVA. Significance was considered to be established when $\mathrm{P} \leq 0.05$.

\section{RESULTS}

Immediate postexposure response: $\mathrm{R}_{\mathrm{L}}$ and $\mathrm{E}_{\mathrm{L}}$ increased significantly in the study group $(\mathrm{n}=11)(\mathrm{P}<0.02)$ at $1 \mathrm{~min}$ postexposure (Table 1, Figure 3). The increase $\left(80 \%\right.$ for $\mathrm{R}_{\mathrm{L}}$ and $67 \%$ for $\mathrm{E}_{\mathrm{L}}$ ) was transient; values returned to baseline within 5 mins. Control animals $(n=3)$ did not demonstrate a significant change in $\mathrm{R}_{\mathrm{L}}$ and $\mathrm{E}_{\mathrm{L}}$ following saline inhalation.

One-week follow-up: Follow-up $\mathrm{R}_{\mathrm{L}}$ and $\mathrm{E}_{\mathrm{L}}$ measurements at $24 \mathrm{~h}$ (day 1) and one week (day 7) postexposure did not change significantly (Figure 4a,b, Table 2). Furthermore, airway responsiveness to Mch did not increase (Table 2, Figure $4 c)$. Control animal values remained unchanged.

\section{DISCUSSION}

Apart from a transient, postexposure increase in $\mathrm{R}_{\mathrm{L}}$ and $\mathrm{E}_{\mathrm{L}}$, we did not demonstrate a significant change in lung mechanics or airway responsiveness, measured $24 \mathrm{~h}$ and one week after the insult. This occurred despite exposure to a

TABLE 1

Lung resistance $(R L)$ and lung elastance $\left(E_{L}\right)$ after exposure to acetic acid

\begin{tabular}{|c|c|c|c|c|c|}
\hline & \multicolumn{5}{|c|}{ Time (min) } \\
\hline & 0 & 1 & 5 & 15 & 30 \\
\hline \multicolumn{6}{|c|}{$\mathrm{RL}$, mean $\pm \mathrm{SD}\left(\mathrm{cm} \mathrm{H} \mathrm{H}_{2} \mathrm{O} / \mathrm{mL} / \mathrm{s}\right)$} \\
\hline Study $(n=11)$ & $0.256 \pm 0.043$ & $0.460 \pm 0.062^{*}$ & $0.286 \pm 0.054$ & $0.247 \pm 0.035$ & $0.253 \pm 0.039$ \\
\hline Control $(n=3)$ & $0.243 \pm 0.036$ & $0.261 \pm 0.049$ & $0.245 \pm 0.037$ & $0.243 \pm 0.040$ & $0.251 \pm 0.032$ \\
\hline \multicolumn{6}{|c|}{$\mathrm{EL}$, mean $\pm \mathrm{SD}\left(\mathrm{cm} \mathrm{H}_{2} \mathrm{O} / \mathrm{mL}\right)$} \\
\hline Study $(n=11)$ & $3.278 \pm 0.493$ & $5.476 \pm 0.695^{*}$ & $3.041 \pm 0.433$ & $3.299 \pm 0.472$ & $3.334 \pm 0.442$ \\
\hline
\end{tabular}

${ }^{*} P<0.02$ versus all other time periods in the same animal and $P<0.01$ versus all time periods in the control animals 

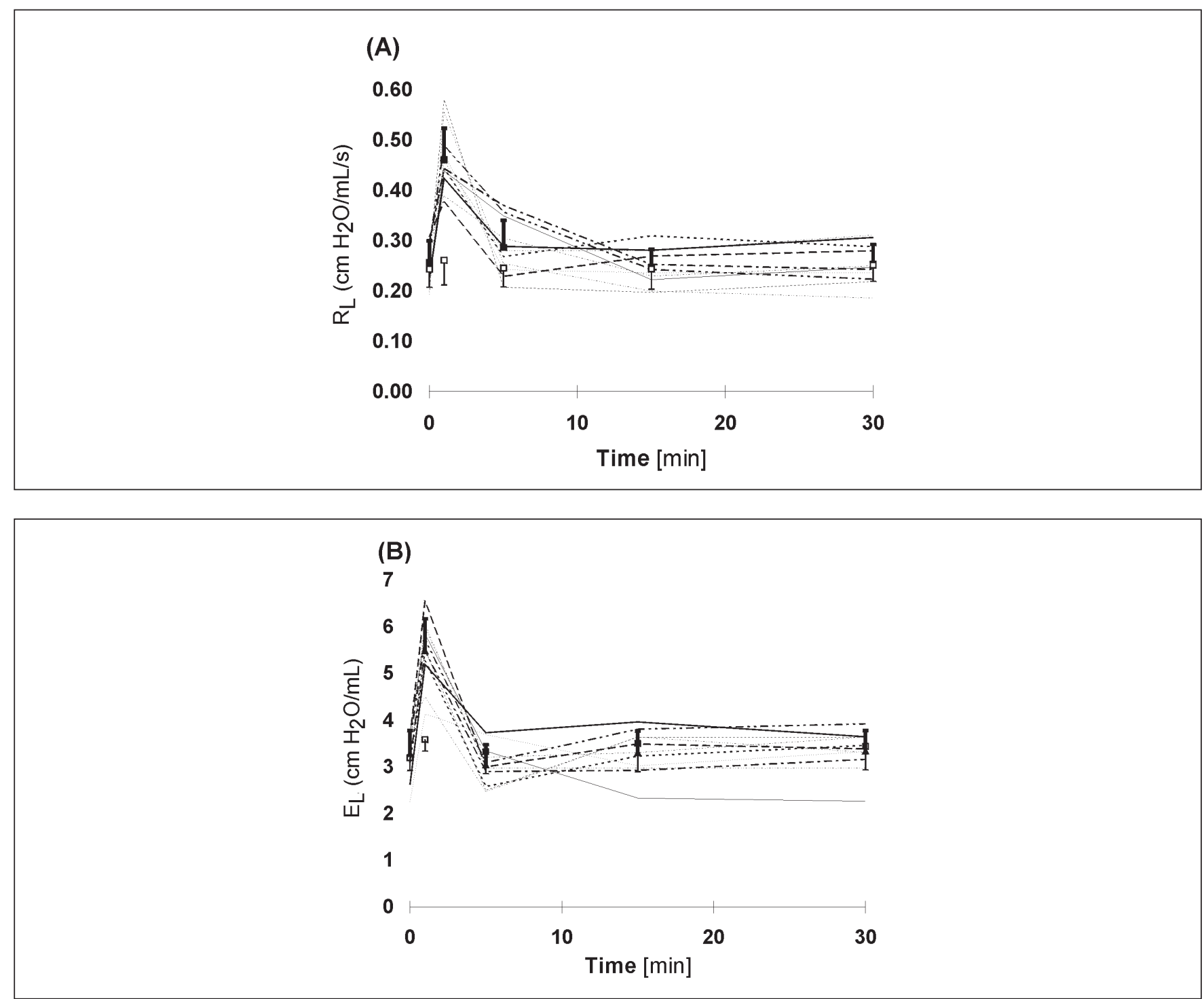

Figure 3) a Postexposure lung resistance $\left(R_{L}\right)$. b Postexposure lung elasticity $\left(E_{L}\right)$. Control animals $(n=3$, open square; mean $\pm S E)$, study group data $(n=11)$, and individual (lines) and group means $\pm S E$ (solid squares) are shown. Both $R_{L}\left(180 \%\right.$ of baseline) and $E_{L}(167 \%$ of baseline) increased transiently at $1 \mathrm{~min}$ postexposure compared with baseline, 5 min and control animal values $(P<0.001)$

concentrated $(8 \mathrm{~N}=50 \%)$ acetic acid solution administered in a manner identical to that of the Mch aerosol. It is, therefore, difficult to assume that irritant delivery to the lower airways failed. It can be argued that studying a larger number of animals would possibly reveal 'irritant susceptible individuals'. However, inbred animal species tend to be uniform in their airway response, as shown in our study (Tables 1,2; Figures 3,4$)$. Furthermore, individual 'asthma-like susceptibility' cannot be consistently demonstrated in animal models. The relative hyper-responsiveness of the Fischer rat strain is probably explained by structural characteristics of parenchymal-airway interdependence (13).

A single study in guinea-pigs (14) demonstrating AHR 14 days after intratracheal instillation of sulphur mustard (a chemical warfare agent) was found in the literature. Transient AHR (measured 90 mins postexposure) was also demonstrated in guinea-pigs exposed to acid-coated, ultrafine fly ash particles (15). AHR could not be demonstrated with ex- posure to either sulphur dioxide or the particles alone. One study in Sprague-Dawley rats reported changes in Mch responsiveness after chlorine gas exposure (16). Other animal studies failed to show AHR, even following recurrent exposures (17). Thus, the agents that have induced AHR in animal models have not been those generally described in human studies.

The great majority of subjects exposed to irritant spills do not develop RADS $(4,10)$. Most symptomatic individuals recover within a few days (18). Early symptoms are often related to upper airway irritation, and are more common in smokers and asthmatics (18). Persistent respiratory symptoms and AHR occur in $10 \%$ or less of exposed individuals. The definition of RADS does not require spirometric evidence of airflow limitation, nor does it necessitate the demonstration of spontaneous airflow variability or a significant bronchodilator response (1). On the contrary, pulmonary function tests are often normal, and when airflow obstruction 

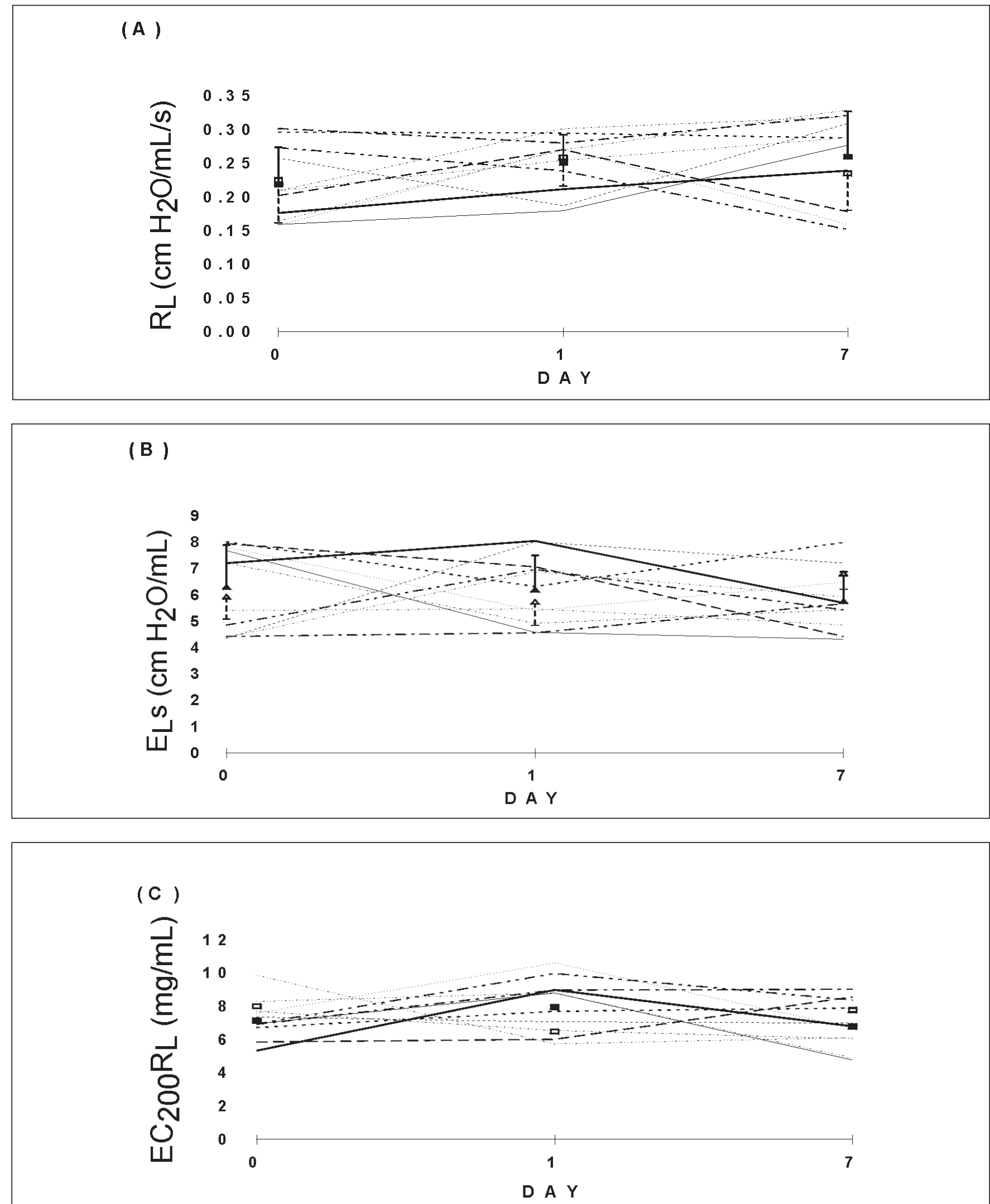

Figure 4) One-week follow-up lung resistance $\left(R_{L}\right)(\mathbf{a})$, lung elasticity $\left(E_{\mathrm{L}}\right)(\mathbf{b})$ and the concentration of methylcholine required to double $R_{L}$ $\left(E C_{200} R_{L}\right)(\mathbf{c})$. Control animals $(n=3$, open symbols; mean $\pm S E)$ and study group data $(n=11)$, and individual (lines) and group means $\pm S E$ (solid squares) are shown. The apparent trend of increase in $R_{L}$ values was not significant. Study group means did not change significantly and were similar to those of the control animals 
exists it may fail to improve significantly with bronchodilation (19). The degree of AHR reported for most cases of RADS is often mild. Pathological findings are not constant with bronchial biopsies showing varying degrees of inflammation and fibrotic changes $(1,7,19)$.

While it is clear that postchemical injury respiratory symptoms associated with AHR do occur, it is still unclear whether they always represent a de novo irritant-induced asthmatic state. Clinical irritant-induced asthma is probably a heterogeneous entity, including cases of previously undiagnosed asthma or nonasthmatic AHR, both of which may predispose the patient to the persistence of respiratory symptoms. Many patients in previous reports had a history of cigarette smoking $(1,7)$; this may have been associated with underlying unrecognized airway disease or hyper-responsiveness. In addition, it is possible that cigarette smoke or other agents may act as cofactors with the high level irritant exposure in the induction of AHR. Other patients, similar to those described by Gautrin et al (19), may have sustained a mild form of fixed airway obstructive disease with AHR.

The present study indicates that induction of airway narrowing following high level inhaled irritant exposure is not sufficient to induce AHR and RADS in Fischer rats and suggests that additional factors play a role in this condition. There may be genetic factors, and a different strain of rats may demonstrate a different response, as suggested by the report of chlorine-induced hyper-responsiveness in SpragueDawley rats (16). Furthermore, differences in delivery method and tissue solubility of the irritant may also account for the different response. Alternatively, the exposure conditions in this study may not have induced a sufficient insult to the airways. A longer exposure or an exposure concentration closer to the lethal concentration may be needed to induce RADS in this model. In addition to the need for an animal model of RADS, there is a need for cross-sectional and prospective studies in the workplaces with moderate respiratory irritant exposures to clarify further the prevalence and incidence of AHR compared with workplaces without irritant exposures. In addition, the investigation of spill events may further define the dose-response relationship.

\section{REFERENCES}

1. Brooks SM, Weiss MA, Bernstein IL. Reactive airways dysfunction syndrome (RADS). Persistent asthma syndrome after high level irritant exposures. Chest 1985;88:376-84.

2. Promisloff RA, Phan A, Lenchner GS, Cichelli AV. Reactive airways dysfunction syndrome in three police officers following a roadside chemical spill. Chest 1989;95:476-7.

3. Deschamps D, Rosenberg N, Soler P, et al. Persistent asthma after accidental exposure to ethylene oxide. Br J Ind Med 1992;49:523-5.

4. Kern DG. Outbreak of the reactive airways dysfunction syndrome after a spill of glacial acetic acid. Am Rev Respir Dis 1991;44:1058-64.

5. Cone JE, Wugofski L, Balmes JR, et al. Persistent respiratory health effects after a metam sodium pesticide spill. Chest 1994;106:500-8.

6. Tarlo SM, Broder I. Irritant-induced occupational asthma. Chest 1989;96:298-300.
TABLE 2

Lung resistance $(R L)$, lung elastance $(E L)$ and the concentration of methylcholine require to double $R_{L}$ $\left(E D_{200} R_{L}\right)$ at baseline, one day and one week postexposure

\begin{tabular}{|c|c|c|c|}
\hline & \multicolumn{3}{|c|}{ Day } \\
\hline & Baseline & 1 & 7 \\
\hline \multicolumn{4}{|l|}{$\begin{array}{l}\mathrm{RL}, \text { mean } \pm \mathrm{SD} \\
\quad\left(\mathrm{cm} \mathrm{H} \mathrm{H}_{2} \mathrm{O} / \mathrm{mL} / \mathrm{s}\right)\end{array}$} \\
\hline Study $(n=11)$ & $0.219 \pm 0.055$ & $0.251 \pm 0.042$ & $0.260 \pm 0.067$ \\
\hline Control $(n=3)$ & $0.225 \pm 0.063$ & $0.259 \pm 0.043$ & $0.235 \pm 0.055$ \\
\hline \multicolumn{4}{|l|}{$\begin{array}{l}\text { EL mean } \pm \mathrm{SD} \\
\left(\mathrm{cm} \mathrm{H} \mathrm{H}_{2} \mathrm{O} / \mathrm{mL}\right)\end{array}$} \\
\hline Study $(n=11)$ & $6.304 \pm 1.595$ & $6.206 \pm 1.293$ & $5.770 \pm 1.122$ \\
\hline Control $(n=3)$ & $5.939 \pm 0.857$ & $5.745 \pm 0.897$ & $6.815 \pm 0.598$ \\
\hline \multicolumn{4}{|c|}{$\begin{array}{l}\mathrm{ED}_{200} \mathrm{R}_{\mathrm{L}} \\
\quad \text { (geometric mean) }\end{array}$} \\
\hline Study $(n=11)$ & 7.142 & 7.959 & 6.784 \\
\hline Control $(n=3)$ & 8.009 & 6.486 & 7.777 \\
\hline
\end{tabular}

Values did not change significantly at one and seven days postexposure. Values were similar between control and study animals

7. Chan-Yeung M, Lam S, Kennedy SM, Frew AJ. Persistent asthma after repeated exposures to high concentrations of gases in pulpmills. Am J Respir Crit Care Med 1994;149:1676-80.

8. Wade JF, Newman LS. Deisel asthma: reactive airways disease following overexposure to locomotive exhaust. J Occup Med 1993;35:149-54.

9. Kipen HM, Blume R, Hutt D. Asthma experience in an occupational and environmental medicine clinic: low-dose reactive airways dysfunction syndrome. J Occup Med 1994;36:1133-7.

10. Alberts WM, do Pico GA. Reactive airways dysfunction syndrome. Chest 1996;109:1618-26.

11. Glindmeyer H, Lefante J, Freyder L, Jones R, Weill H. Prospective study of a large working population provides no evidence of irritant-induced asthma. Am J Respir Crit Care Med 1995;151(Suppl):A420. (Abst)

12. Bherer L, Cushman R, Courteau JP, et al. Survey of construction workers repeatedly exposed to chlorine over a 3 to 6 month period in a pulpmill: II. Follow-up of affected workers by questionnaire, spirometry, and assessment of bronchial responsiveness 18 to 24 months after exposure ended. Occup Environ Med 1994;51:225-8.

13. Dandurand RJ, Xu LJ, Martin JG, Eidelman DH. Airway parenchymal interdependence and bronchial responsiveness in two highly inbred rat strains. J Appl Physiol 1993;74:538-44.

14. Clavet JH, Jarreau PH, Lavame M, et al. Acute and chronic respiratory effects of sulfur mustard intoxication in guinea pig. J Appl Physiol 1994;76:681-8

15. Chen LC, Miller PD, Amdur MO, Gordon T. Airway hyperresponsiveness in guinea pigs exposed to acid-coated ultrafine particles. J Toxicol Environ Health 1992;35:165-74.

16. Demnati R, Fraser R, Plaa G, Martin JG, Malo J-L. Functional abnormalities after acute exposure to chlorine gas in Sprague-Dawley rats. Am Rev Respir Crit Care Med 1996;153:A182. (Abst)

17. Klonne DR, Ulrich CE, Riley MG, Hamm TE Jr, Morgan KT, Barrow CS. One-year inhalation toxicity study of chlorine in rhesus monkeys (Mucaca mulatta). Fundam Appl Toxicol 1987;9:557-72.

18. Blanc PD, Galbo M, Hiatt P, Olson KR, Balmes JR. Symptoms, lung function, and airway responsiveness following irritant inhalation. Chest 1993;103:1699-705.

19. Gautrin D, Boulet LP, Boutet M, et al. Is reactive airways dysfunction syndrome a variant of occupational asthma? J Allergy Clin Immunol 1994;93:12-22. 


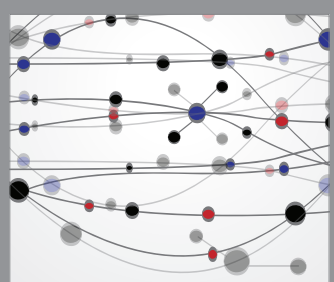

The Scientific World Journal
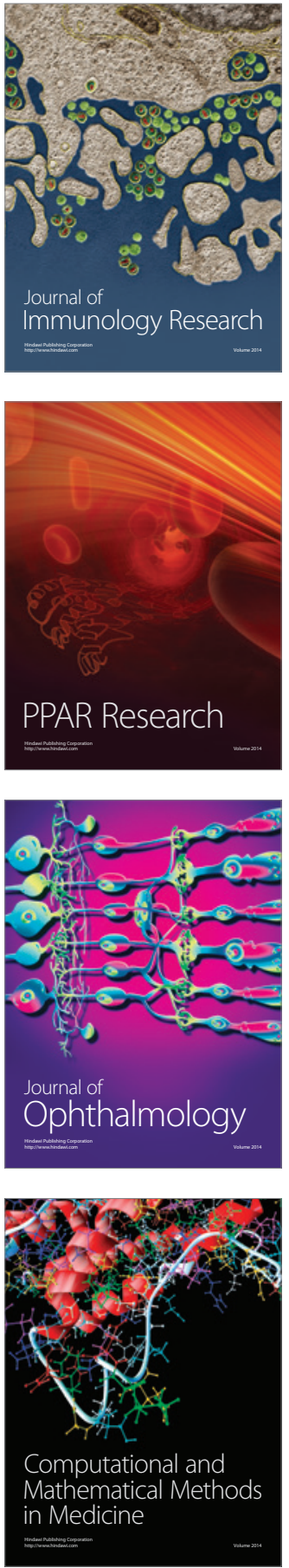

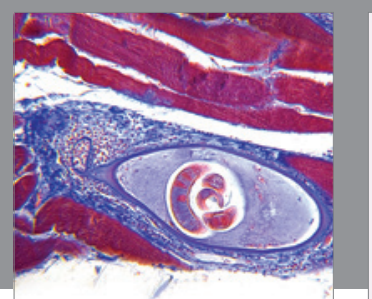

Gastroenterology Research and Practice

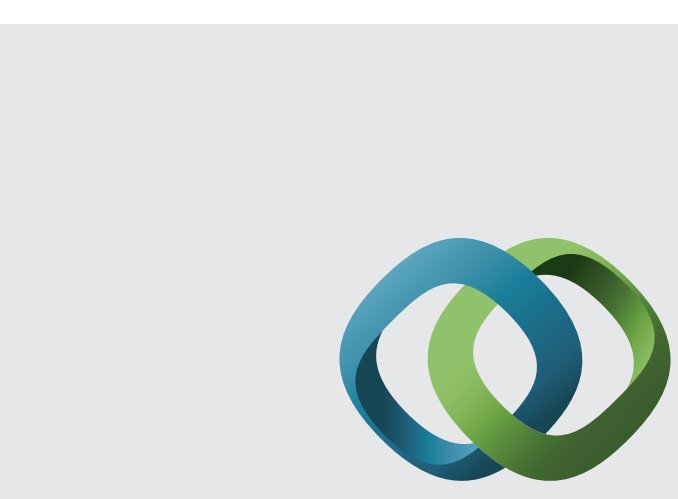

\section{Hindawi}

Submit your manuscripts at

http://www.hindawi.com
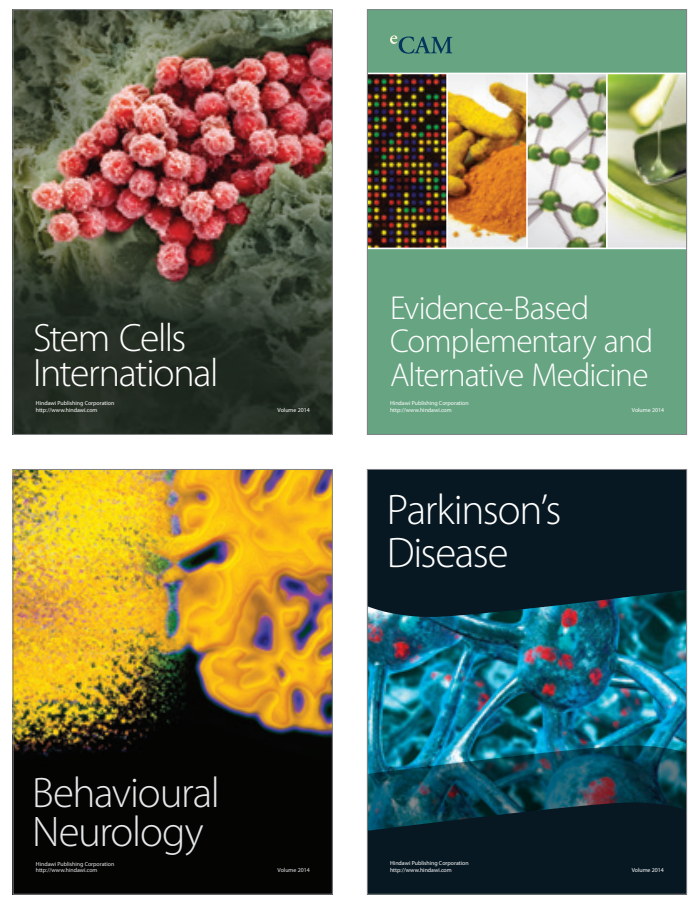
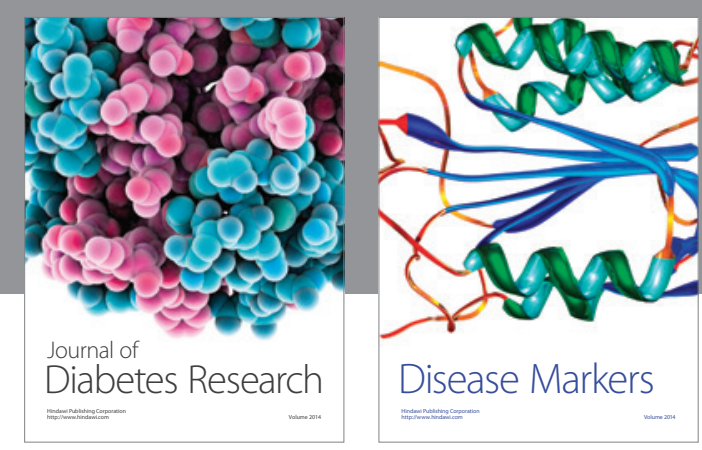

Disease Markers
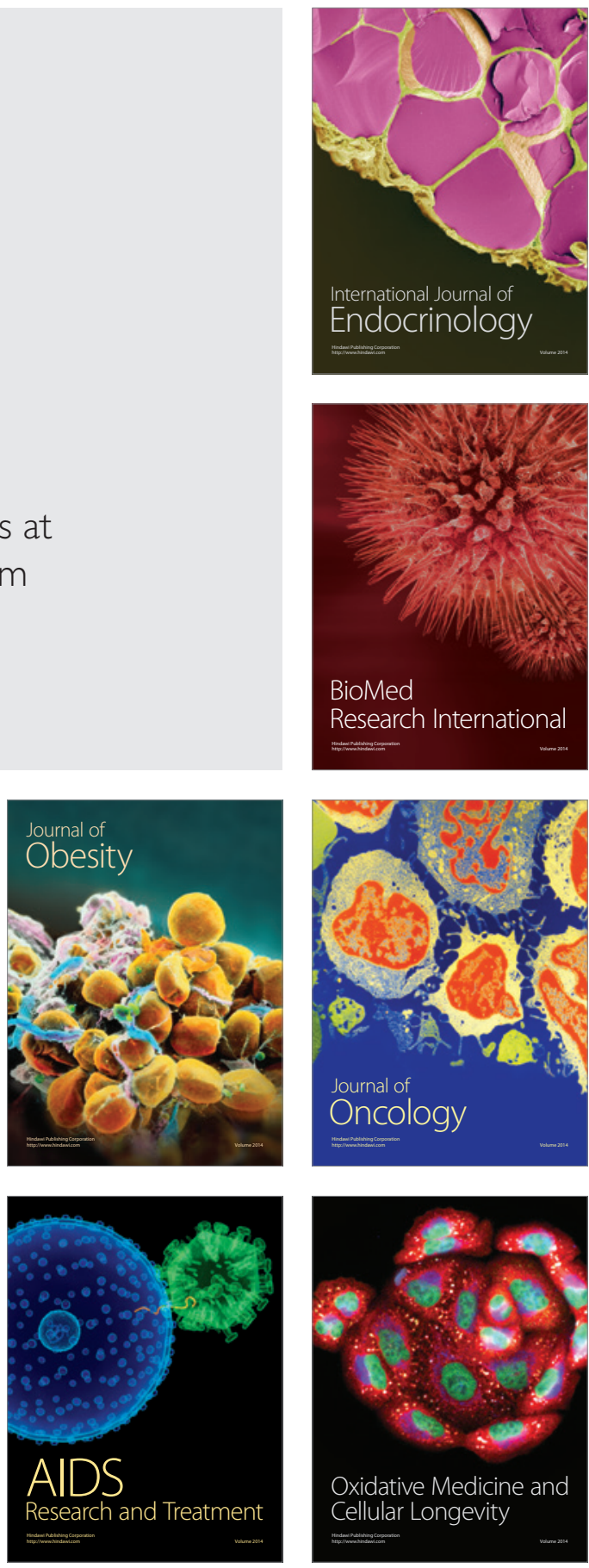